\title{
METHODS
}

UDC 577.1:112.386+543.42+616.895.8

doi: https://doi.org/10.15407/ubj88.05.107

\section{MEASUREMENT OF METHIONINE LEVEL WITH THE LC-ESI-MS/MS METHOD IN SCHIZOPHRENIC PATIENTS}

\author{
S. KULAKSIZOGLU', B. KULAKSIZOGLU', H. Y. ELLIDAG \\ E. EREN $N^{1}$, N. YILMAZI, A. BAYKAL $L^{3}$
}

${ }^{1}$ Central Laboratories of Antalya Education and Research Hospital, Department of Biochemistry, Antalya, Turkey; e-mail: sblclngrgl@yahoo.co.uk;

${ }^{2}$ Antalya Education and Research Hospital, Department of Psychiatry, Antalya, Turkey;

${ }^{3}$ Akdeniz University School of Medicine, Department of Biochemistry, Antalya, Turkey

The purpose of this study was to evaluate plasma methionine levels by using liquid chromatography electrospray ionization-tandem mass spectroscopy (LC-ESI-MS/MS) in schizophrenic patients. A twelvepoint standard graph was drawn, and the recovery rate, the intra-day and inter-day coefficients of variation $(C V)$, the limit of detection (LOD), and the limit of quantification ( $L O Q)$ were evaluated. The $y$ and $R^{2}$ values of the standard graph equation were determined as $0.011 x+0.0179$ and 0.9989 , respectively, and the graph remained linear until the $200 \mu \mathrm{mol} / \mathrm{l}$ level. The intra-day coefficients of variation of the samples $(n=10)$ containing 8, 28, and 58 umol/l methionine were determined as 2.68, 3.10, and 3.79\%, respectively; while their inter-day coefficients of variation were determined as 2.98, 3.19, and 3.84\%. The LOD and LOQ values were determined as 0.04 and $0.1 \mu \mathrm{mol} / \mathrm{l}$, respectively, while the mean recovery rates were determined as 101.7 and 99.3\%. Plasma methionine values were measured as 21.5 (19.5-24,6) $\mu$ mol/l for the patient group, 17.8 (16.320.1) $\mu \mathrm{mol} / \mathrm{l}$ for the control group, and the difference between the two groups was statistically significant ( $p=0.03)$. LC-ESI-MS/MS method represents a fairly sensitive, economic, and rapid analysis that requires very little sample and is suitable for measuring methionine levels in schizophrenic patients.

Key words: Methionine, LC-ESI-MS/MS, limit of detection (LOD), limit of quantification (LOQ), schizophrenic patients.

$\mathrm{M}$ ethionine is a sulfur-containing amino acid that plays a very important role in methylation reactions. As protein, lipid, and DNA metabolisms, neurotransmitter synthesis and detoxification processes all involve methylation reactions, methionine is of vital importance for normal cellular functions [1, 2]. Methionine has been demonstrated to be involved in many disorders such as schizophrenia, depression, cardiovascular diseases, and obesity. As any impairment of the homocysteine-methionine cycle will affect serum methionine levels, assessing plasma methionine levels is fairly important for understanding their relationships with diseases [3]. Nowadays, the correlation of methionine with diseases is being investigated, especially within the frame of methylation reactions.
Routine measurements of methionine are generally performed by using high-performance liquid chromatography (HPLC), fluorescence polarization immunoassay (FPIA), enzyme immunoassay (EIA) and gas chromatography (GC). However, for reasons such as its ease of preparation and its ability to provide results rapidly, the liquid chromatography electrospray ionization-tandem mass spectroscopy (LC-MS/MS) represents a more suitable method for routine assessments. Owing to its high sensitivity and reliability, the use of LC-MS/MS is gradually increasing in the field of medicine [4]. Although the most common area of its use is currently the diagnosis of metabolic diseases, the LC-MS/MS method is increasingly being used for the analysis and assessment of many different compounds such as proteins, 
lipids, carbohydrates, and DNA. Mass spectrometers are devices whose operating principle is based on analyzing charged particles moving through a magnetic or electrical field, and by distinguishing them from other charged particles according to their mass/ charge $(\mathrm{m} / \mathrm{z})$ ratios. In addition, mass spectrometers are named according to their source of ionization. In this study, we made use of the electrospray ionization (ESI) method [5, 6].

Quantitative accuracy in LC-ESI-MS/MS is ensured through the addition of a suitable internal standard (IS) at the beginning of the analytical procedure. The addition of a known quantity of IS eliminates - both during extraction and analysis all errors associated with substance losses, which might occur at any stage. Thus, the use of an IS in this method remedies systematic and random errors. Deuterium-labelled compounds are commonly used as an IS. Owing to their structural similarity, deuterium-labelled IS have the same chromatographic retention time (RT) as the compound being analyzed. In quantitative measurements, the density or area of the sample will be proportioned with the density or area of IS, and the sample's concentration will be, accordingly, determined from calibration curve $[7,8]$.

There is only the limited number of published studies in which the LC-ESI-MS/MS method is used for the measurement of plasma methionine levels. In addition, these studies generally provide different results due to the differences in their sources of ionization, columns, mobile phases, mobile phase speeds, and deproteinization solutions $[3,9,10]$. The aim of the current study is to evaluate the possibilities of HPLC-ESI-MS/MS method usage for measuring plasma methionine levels.

\section{Materials and Methods}

Materials and solutions. The materials and solutions used in this study included the methionine standard (Fluka FL-64340), the internal standard L-methionine-D3 (Cambridge Isotope Laboratory/DLM-431), LC-MS grade water (Merck/1.15333.2500), DL-1,4 dithiothreitol (Merck/
D9779), LC grade acetonitrile (Merck/M1.00030), LC grade formic acid (Merck/1.00264.1000), TFAA (triflouroacetic acid) (Merck/8.08260.0100), LC grade methanol (Merck/1.06008.2500), a Waters Alliance HPLC unit, and Waters Symmetry C8 reverse phase column $(2.1 \times 100 \mathrm{~mm}, 3.5 \mu \mathrm{m})$ (Muskegon, Michigan, USA).

Case selection. Schizophrenia patients and healthy controls were included in this study, with the aim of evaluating the LC-ESI-MS/MS method with regard to the measurement of plasma methionine levels. In this context 62 patients aged 18-65 (26 females and 36 males with a mean age of $33.79 \pm 8.23$ years), diagnosed with schizophrenia and schizoaffective disorder according to the DSM-IV diagnosis criteria (American Psychiatric Association, Diagnostic and Statistical Manual of Mental Disorders, IV. Edition 1994), and who gave their voluntary consent regarding participation, were included in this study, along with 57 healthy controls (23 females and 34 males with a mean age of $33.66 \pm 8.67$ years). The plasma methionine levels of both the schizophrenia patients and the healthy controls were then measured. The blood samples were collected into $6 \mathrm{ml} \mathrm{K} 2$ EDTA tubes, taken to a centrifuge within $15 \mathrm{~min}$, while being kept in an ice-filled container, and then centrifuged at $4000 \mathrm{rpm}$ for $5 \mathrm{~min}$. Following centrifugation, the plasma of these samples were separated, transferred into four Eppendorf tubes, and then stored at $-80^{\circ} \mathrm{C}$ for further evaluation.

LC-ESI-MS/MS analysis. Plasma methionine levels were measured with an LC-MS/MS device in other words, a liquid chromatography tandem mass spectrometry device (Waters Alliance HPLC; Quattro Micro Triple Quadrupole Tandem Mass spectrometer Waters, Milford, MA, USA).

The positive electrospray ionization was used as the ionization method. Each analysis/test was evaluated under the multiple reaction monitoring (MRM) mode. The ions formed following decomposition, as well as their retention time in the column, their primary ion, secondary ion, and collision energy (CE) are provided in Table 1.

Table 1. The retention time, $\mathrm{m} / \mathrm{z}$ value, and collision energy of the methionine measurements

\begin{tabular}{l|c|c|c|c}
\hline \multicolumn{1}{c|}{ Analytes } & $\begin{array}{c}\text { Retention } \\
\text { time }(\mathrm{min})\end{array}$ & Primary ion $[\mathrm{m} / \mathrm{z}]$ & $\begin{array}{c}\text { Secondary } \\
\text { ion }[\mathrm{m} / \mathrm{z}]\end{array}$ & $\begin{array}{c}\text { Collision energy } \\
\mathrm{CE}[\mathrm{eV}]\end{array}$ \\
\hline Methionine & 1.35 & 150 & 103.8 & $15 \mathrm{eV}$ \\
Methionine-D3 & 1.35 & 153 & 107.1 & $15 \mathrm{eV}$ \\
\hline
\end{tabular}


The Waters Alliance HPLC unit and the Waters Symmetry C8 reverse phase column $(2.1 \times 100 \mathrm{~mm}$, $3.5 \mu \mathrm{m}$ ) (Muskegon, Michigan, USA) were used for the separation process. The mobile phase consisted of $30 \%$ methanol and $0.1 \%$ formic acid, and was evaluated at a speed of $250 \mu \mathrm{l} / \mathrm{min}$. The conditions used for mass spectrometry are provided in Table 2 .

The first procedure for the determination of plasma methionine levels involves reducing methionine molecules bonded to proteins and to each other through disulfide bonds by using dithiothreitol (DTT). Following this, protein precipitating reactants such as methanol and trifluoroacetic acid (TFAA) will be used to remove proteins from the medium/environment (11). In this study, we used acetonitrile, formic acid, and TFAA as precipitants.

Procedure for preparing solutions. The study solutions were prepared in the following concentrations: internal standard L-methionine- $\mathrm{D}_{3}$ at $100 \mu \mathrm{mol} / \mathrm{l}$; methionine standard at $200 \mu \mathrm{mol} / \mathrm{l}$; the reducing agent DTT at $250 \mathrm{mM}$; and the precipitating solution of acetonitrile, formic acid, TFAA (triflouroacetic acid) at a ratio of 99.875:0.1:0.025 respectively. The mobile phase was prepared by using $300 \mathrm{ml}$ of methanol, $699 \mathrm{ml}$ of LC-MS grade water, and $1 \mathrm{ml}$ of formic acid. The flow rate was adjusted as $250 \mu \mathrm{l} / \mathrm{min}$.

For the preparation of the blind solution, twice the volume of acetonitrile was added to a plasma pool consisting of 20 plasma samples, and the mixture was centrifuged at $16,000 \mathrm{~g}$ for $3 \mathrm{~min}$. The supernatant was separated and diluted three times with water, and then used as a blind solution. Control solutions were prepared by diluting the standard stock solutions prepared with water with the blind solution, such that final concentrations of $25 \mu \mathrm{mol} / 1$

Table 2. Mass spectrometry conditions for the measurement of methionine

\begin{tabular}{lc}
\hline \multicolumn{1}{c|}{ Conditions } & Specifications \\
\hline Injection volume & $4 \mu \mathrm{l}$ \\
Ionization mode & ESI positive \\
Nebulizing gas pressure & $55 \mathrm{psi}$ \\
Capillary voltage & $40 \mathrm{v}$ \\
Type and pressure & \\
of decomposing gas & $\mathrm{Ar}, 5.0 \times 10^{-3} \mathrm{mbar}$ \\
Detector voltage & $1600 \mathrm{v}$ \\
\hline
\end{tabular}

and $50 \mu \mathrm{mol} / 1$ of methionine would be obtained. The control samples were stored at $-40{ }^{\circ} \mathrm{C}$.

Study procedure. Twenty $\mu 1$ of plasma (control or standard) and $20 \mu \mathrm{l}$ of $25 \mu \mathrm{mol} / 1$ internal standard (L-methionine- $\mathrm{D}_{3}$ ) were mixed by vortexing for $10 \mathrm{~s}$. Following this, $40 \mu \mathrm{l}$ of $250 \mathrm{mM}$ DTT was also added, and the mixture was vortexed for $30 \mathrm{~s}$ and then kept at room temperature for $5 \mathrm{~min}$. Finally, $200 \mu \mathrm{l}$ of precipitating solution was added, after that the mixture was vortexed for $10 \mathrm{~s}$, and then centrifuged at $13,000 \mathrm{~g}$ for $5 \mathrm{~min}$. To perform readings, the obtained supernatant was transferred in aliquots of $20 \mu \mathrm{l}$ into a culture plate with 96 wells, and then placed into the device. The plasma, control, and standard samples were read and measured using the same procedure.

To test the applicability of the method, the serum methionine levels of 62 patients diagnosed with schizophrenia and of 57 healthy controls were measured using the LC-MS/MS method.

Statistical analysis was performed by using the Mann-Whitney U test on the SPSS 18 program. $P<0.05$ (95\% significance level) were considered statistically significant.

\section{Results and Discussion}

Methionine standard graph. To plot the standard graph, the $200 \mu \mathrm{mol} / 1$ methionine standard solution was first diluted with the blind solution to obtain standard samples with cocentrations of 0,1 , $2,5,10,15,20,40,80,120,160$, and $200 \mu \mathrm{mol} / 1$. For the evaluation of the matrix effect, all standards, except for the blind solution, were prepared by using water. Measurements were performed by applying the procedure described above. Each standard was read twice. The methionine content of the samples and control solutions were calculated by using this standard graph. The standard graph of methionine was drawn by plotting the methionine concentration versus the peak area ratio of the methionine standard to the L-methionine- $\mathrm{D}_{3}$ internal standard. It was observed that the graph was linear $\left(R^{2}=0.9989\right)$ (Fig. 1). The linearity of the standard graph prepared with water was calculated as $y=0.0123 x+0.038$ $\left(R^{2}=0.9998\right)$. After the standard graph was plotted, the blind solutions were read and evaluated.

No peak was identified during the evaluation of the blind solutions for methionine. After the standard graph was plotted, the blind solutions were read and evaluated (Fig. 2).

An example of a plasma methionine chromatogram for a patient is shown in Fig. 3. 


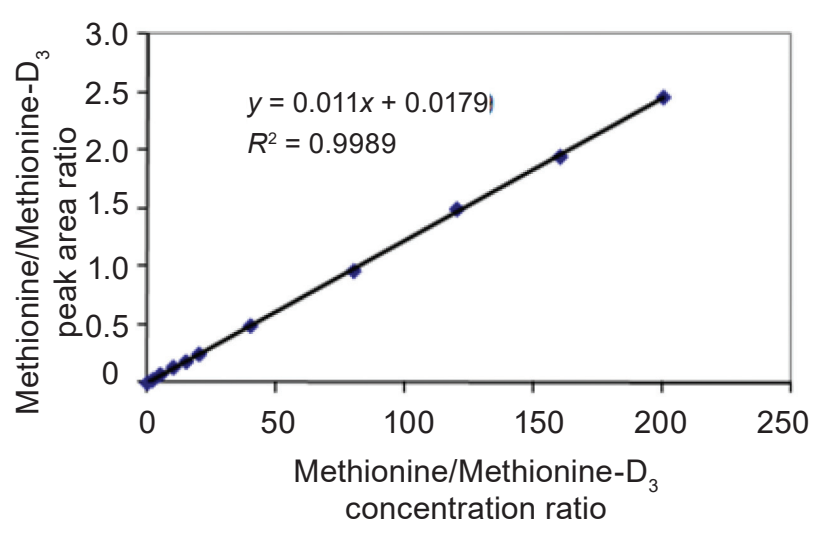

Fig. 1. Methionine standard graph

Following this, the control solutions prepared at two different doses were measured twice, and the mean value of these two measurements was determined for each one of the control solutions. The mean values for the 25 and $50 \mu \mathrm{mol} / 1$ controls were determined as 25.05 and $49.66 \mu \mathrm{mol} / 1$, respectively. After the controls were evaluated, measurements were performed on the samples. The intra-day reproducibility, inter-day reproducibility and recovery for methionine were evaluated.

A plasma pool was prepared using 20 plasma samples. In this approximately $10 \mathrm{ml}$ plasma pool, the methionine level was measured as $16.15 \mu \mathrm{mol} / \mathrm{l}$. The plasma pool sample was transferred to $30 \mathrm{Ep}$ pendorf tubes in equal aliquots of $10 \mu 1$. Solutions with methionine concentrations of 0,40 , and $100 \mu \mathrm{mol} / 1$ were prepared.

The 30 samples were divided into three sets of ten. Following this, $10 \mu \mathrm{l}$ of water and $10 \mu \mathrm{l}$ of the plasma pool solution were added to the first of the three sets; $10 \mu 1$ of $40 \mu \mathrm{mol} / 1$ solution and $10 \mu \mathrm{l}$ of the plasma pool solution were added to the second of the three sets; and $10 \mu \mathrm{l}$ of $100 \mu \mathrm{mol} / 1$ solution and $10 \mu \mathrm{l}$ of the plasma pool solution were added to the third of the three sets. The mixtures were all vortexed for ten seconds, and then stored at $-20^{\circ} \mathrm{C}$.

To evaluate yield (recovery), the samples prepared at three different concentrations were consecutively measured ten times. Calculated yields varied between $94.4-106.9 \%$. The mean yield was calculated as $101.7 \%$ and $99.3 \%$. In the evaluation of intra-day reproducibility, the mean concentrations of the samples measured ten times within the same day were $8.07,28.53$, and $57.49 \mu \mathrm{mol} / 1$. The coefficient of variation $(\mathrm{CV})$ was calculated as 2.68 , 3.1 , and $3.79 \%$, respectively. To evaluate inter-day reproducibility, the samples prepared at three different concentrations were measured on ten different
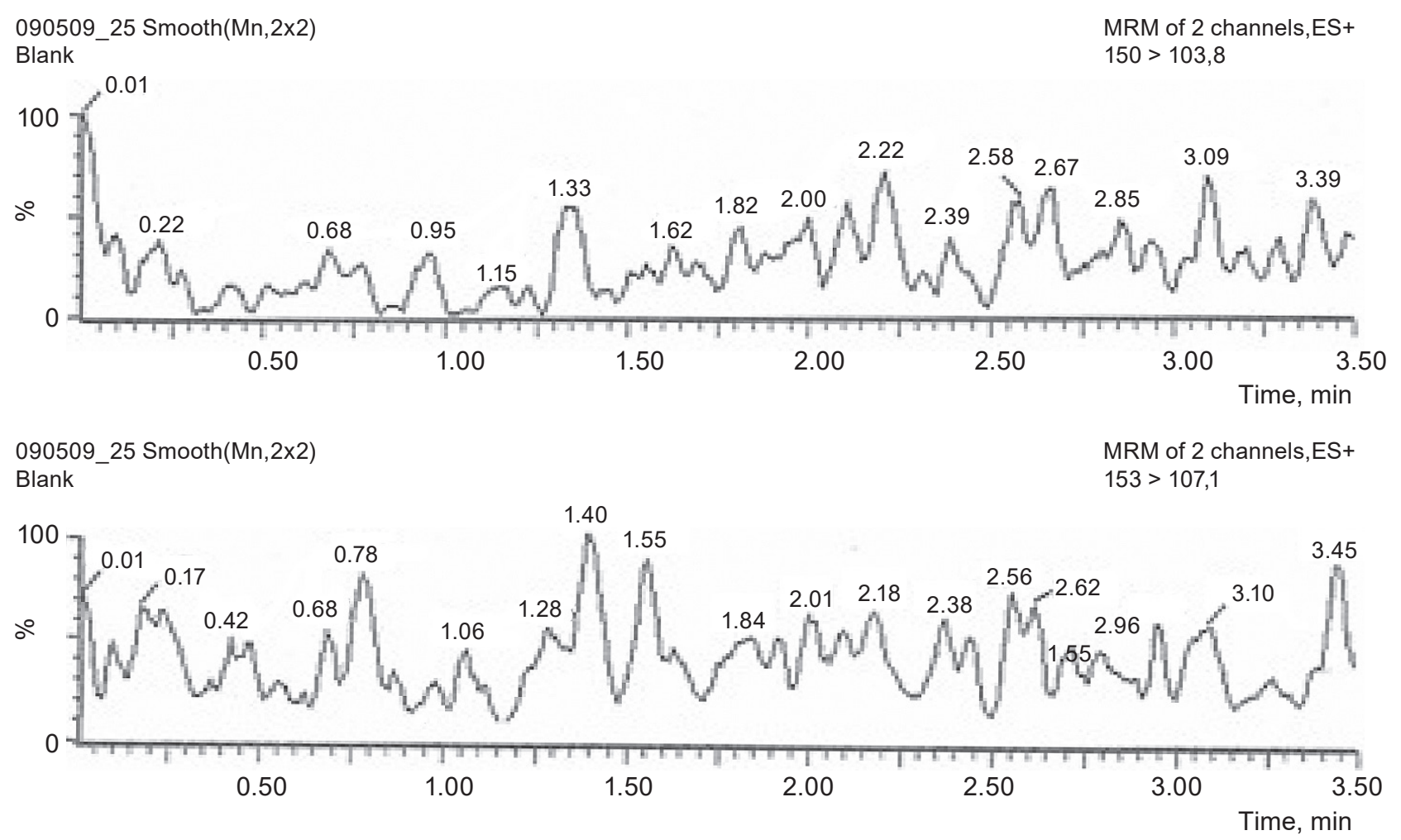

Fig. 2. Chromatogram of blind solution for methionine 


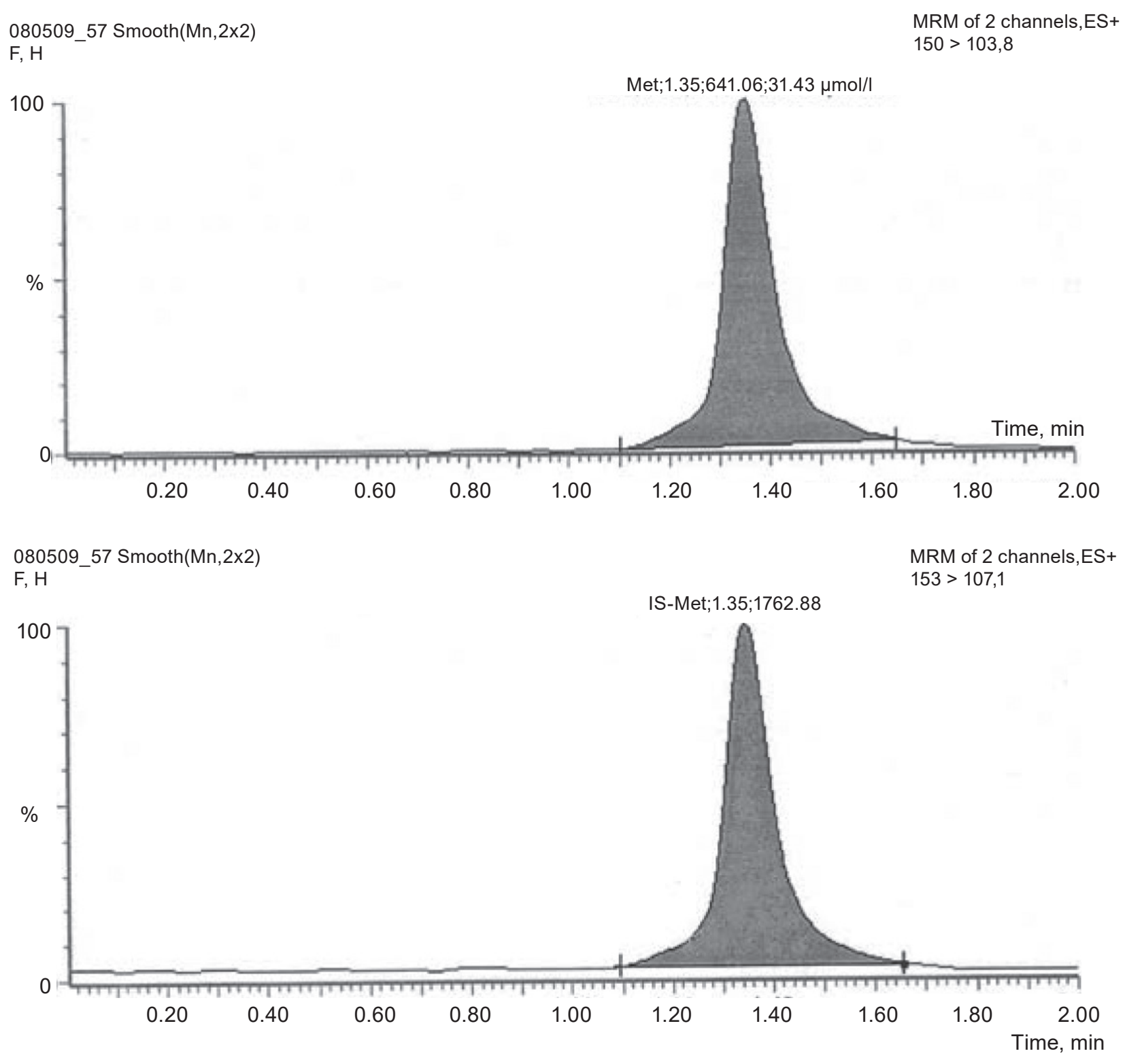

Fig. 3. Methionine chromatogram of a patient

Ta ble 3. Evaluation of intra-day reproducibility, inter-day reproducibility, and recovery for methionine

\begin{tabular}{c|c|c|c|c|c}
\hline $\begin{array}{c}\text { Number } \\
\text { of Tests }\end{array}$ & $\begin{array}{c}\text { Methionine, } \\
\mu \mathrm{mol} / \mathrm{l}\end{array}$ & $\begin{array}{c}\text { Measured, } \\
\mu \mathrm{mol} / 1\end{array}$ & Recovery & Intra-day & Inter-day \\
\hline $\mathrm{N}=10$ & 0 & $8.01 \pm 0.21$ & & $\mathrm{CV} \%: 2.68$ & $\mathrm{CV} \%: 2.95$ \\
$\mathrm{~N}=10$ & 20 & $28.36 \pm 0.88$ & $101.7 \%$ & $\mathrm{CV} \%: 3.10$ & $\mathrm{CV} \%: 3.19$ \\
$\mathrm{~N}=10$ & 50 & $57.68 \pm 2.18$ & $99.3 \%$ & $\mathrm{CV} \%: 3.79$ & $\mathrm{CV} \%: 3.84$ \\
\hline
\end{tabular}

days, and their means and standard deviations were calculated. The mean concentrations of the samples were determined as $8.01 \pm 0.21,28.36 \pm 0.88$, and $57.68 \pm 2.18 \mu \mathrm{mol} / 1$, respectively, while their CV\% was determined as $2.95,3.19$, and $3.84 \%$, respective- ly. The $\mathrm{CV} \%$ values obtained in the evaluations of reproducibility and yield are presented in Table 3 .

Limit of detection (LOD), defined as the minimum concentration of methionine giving a peak area three-fold the noise. Limit of quantification (LOQ), 
defined as the lowest concentration of methionine, which can be measured in triplicate with a precision higher than $20 \%$ (11). Methionine content was measured ten times in the $0.5 \mu \mathrm{mol} / 1$ sample, and, based on the formula $\mathrm{LOD}=3 \mathrm{x}$ standard deviation, the LOD was calculated as 0.04 . Based on the formula LOQ $=10 \times$ standard deviation, the LOQ was calculated as $0.1 \mu \mathrm{mol}(9)$.

The mean plasma methionine level of the 62 schizophrenia patients and 57 controls were determined as 21.5 (19.5-24.6) $\mu \mathrm{mol} / 1$ and 17.8 (16.320.1) $\mu \mathrm{mol} / 1$, respectively. The difference between the two groups was statistically significant $(p=0.03)$.

The amino acid methionine is known to be involved in many diseases such as schizophrenia, depression, cardiovascular diseases, and obesity. It is an important mediator in the single-carbon metabolism and methylation reactions $[2,3]$. The measurement of methionine levels is of considerable importance for studies attempting to gain an understanding of the relationship between methylation reactions and diseases. The liquid chromatography electrospray ionization-tandem mass spectroscopy (LC-ESI-MS/MS) is a fairly sensitive, low-cost and reliable measurement method [6]. However, the LCMS-MS method is also associated with disadvantages such as the requirement for preparation, and experienced/specialized personnel.

In studies, standards must be prepared in conditions similar to those of the matrix [11]. To investigate the matrix effect, we compared the calibration curves prepared using water and plasma. The equations of the both curves were very close to one another. The graph equation of the standards prepared with water was $y=0.0123 x+0.038\left(R^{2}=0.9998\right)$, while the the graph equation of the standards diluted with blind solution was $y=0.011 x+0.0179$ $\left(R^{2}=0.9989\right)$.

Total homocysteine levels were previously evaluated with the LC-ESI-MS/MS method by Persichilli et al. [11] in 2008, and by Li et al. [12] in 2008; they described no significant differences between the calibration curves of samples prepared with water and plasma. These observations suggest that the LCMS/MS is a fairly sensistive method that is minimally affected by environmental artefacts, owing to its ability to separate/distinguish the molecules being evaluated as primary and secondary molecules, and to perform measurements in the presence of an internal standard. In measurements where the matrix effect is not taken into consideration, the method of adding standards to the plasma is employed instead. The obtained data indicates recovery. The recovery minimizes the errors that might stem from the matrix effect or the standard added to the samples $[11,13]$. The mean recovery values in our study were of 101.7 and $99.3 \%$ that was better compared to other studies. Weaving et al. (2006) reported recovery values of 94.7 and $93.4 \%$, while Gardner et al. (2013) reported a recovery value of $97 \%[9,10]$.

The first necessary procedure for the determination of plasma methionine levels is the reduction of plasma-bound methionine molecules to free methionine. To achieve this, tris(2-carboxyethyl)phosphine (TCEP) and dithiothreitol (DTT) are commonly used [14]. It has been previously demonstrated that, compared to DTT, TCEP provides certain advantages such as higher peaks, less noise (unnecessary signals), and greater stability in acidic and basic environments. However, DTT is associated with better reproducibility of results compared to TCEP [14].

Hempen et al. (2008) and Raifi et al. (2007) used TCEP in their studies assessing homocysteine levels $[15,16]$. In the current study, we observed irregularities in the chromatograms of samples prepared with DTT and kept at $-20{ }^{\circ} \mathrm{C}$ for more than 24 hours. We believe that this was due to the early vaporization and oxidation property of DTT. We always prepared a fresh DTT solution for each test, in order to eliminate any problems that might stem from vaporization and oxidation during storage. This might have contributed to the better intra- and interday reproducibility values obtained in this study. In the current study, the intra-day reproducibilities of samples with 8,28 , and $58 \mu \mathrm{mol} / 1$ methionine were between 2.6 and $3.7 \%$, while the inter-day reproducibilities of these samples were between 2.9 and $3.8 \%$. Weaving et al., on the other hand, determined that the intra-day reproducibilities of samples with 20 and $50 \mu \mathrm{mol} / 1$ methionine were between 2.96 and $3.7 \%$, while the intra-day reproducibilities of these samples were between 11.1 and $12.7 \%$ [9]. As mentioned above, the recovery data of our study were also comparatively better. These findings indicate that our method was more sensitive than those used in other studies. In addition, within the context of this study, we used 30\% methanol and $0.1 \%$ formic acid in our mobile phase. On the other hand, Weaving et al. used $50 \%$ acetonitrile and $0.1 \%$ formic acid, while Gardner et al. used acetonitrile and 0.1\% acetic acid in their studies [9, 10]. Furthermore, 
our study also differed in that we used acetonitrile, formic acid and TFAA for deproteinization, while Gardner et al. used methanol for deproteinization. Based on these data, it is possible to state that the use of methanol in the mobile phase and the use of acetonitrile, formic acid, and TFAA for deproteinization represent preferable choices for obtaining better $\mathrm{CV} \%$ and recovery values.

The retention time refers to the time that passes between the sample's first entry into the column and the highest detector response following its exit from the column. While every substance has a different retention time, the measured substance and its internal standard retention times' are similar [14]. The retention time is affected by many factors such as the mobile phase content, the mobile phase speed, the column length, and the diameter of pores covering the column. In our study, the retention time was determined as $1.35 \mathrm{~min}$. On the other hand, Gardner et al. determined the retention time of four minutes in their study [10], while Calderon-Santiago et al. determined the retention time as 9.2 minutes [3]. The retention time of our study was considerably shorter than the times observed in these studies. The shorter retention times we observed could have been associated with the use of methanol in the mobile phase, and the use of acetonitrile, formic acid, and TFAA at a ratio of 99.875:0.1:0.025 for deproteinization. Gardner et al. and Calderon-Santiago et al. describe using acetonitrile as the mobile phase, and methanol for deproteinization. Shorter retention times are important in that they allow a greater number of samples to be evaluated within a shorter period of time. Shorter analysis periods represent an important criterion for measurement methods; in this context, our study method permitted the evaluation of 33 samples in one hour (including the ten minute pre-preparations), while Gardner et al.'s and Calderon-Santiago et al.'s methods permitted the evaluation of eleven and five samples an hour, respectively [10, 3].

To increase selectivity and the limits of detection, samples are normally subjected to extraction and chromatographic dissociation prior to MS procedures. Columns used for liquid chromatography are important for the pre-preparation procedures of LC-MS/MS. These columns are divided into two groups as normal phase and reverse phase columns. In this study, we made use of an HPLC unit and a C8 reverse phase column. Reverse phase columns present several advantages, such as a slower elution rate, the associated slowing of peaks, and the fact that smaller changes in the mobile phase result in significant changes on the chromatograms [17]. For these reasons, the reverse phase column was preferred for our study.

Other important parameters of application studies include the LOD and the LOQ, with lower values for these parameters indicating higher sensitivity $[10,11]$. In the current study, the LOD and LOQ were determined as 0.04 and $0.1 \mu \mathrm{mol} / 1$, respectively. In their study investigating plasma methionine levels with the LC-MS/MS method, Gardner et al. identified an LOD value of $5 \mu \mathrm{mol} / 1$ [10]. Weaving et al., on the other hand, determined LOD and LOQ values of 0.2 and $0.4 \mu \mathrm{mol} / 1$, respectively, in a similar study [9]. The considerably lower LOD and LOQ values we obtained in comparison to other studies indicated that our method had good sensitivity. We believe that these differences might have also stemmed from the different substances we used in the mobile phase and for deproteinization

In this study, where we evaluated plasma methionine levels using the LC-ESI-MS/MS method, the mean plasma methionine levels of 62 schizophrenia patients was identified as 21.5 (19.5-24.6), while the mean plasma methionine levels of the 57 healthy control was identified as $17.8(16.3-20.1) \mu \mathrm{mol} / 1$ $(p=0.03)$. The increased methionine levels in schizophrenia patients suggest an association between schizophrenia and methylation reactions [1]. Studies have demonstrated a relationship between the methylating amino acid methionine and the positive symptoms of schizophrenia [18]. Further studies could also be performed on the correlation between plasma methionine levels and other parameters of the methylation cycle in schizophrenia patients.

Studies on the plasma levels of methionine and amino acid, closely associated with methylation reactions, are of considerable importance. The LCESI-MS/MS method presents various advantages over other methods, such as its ability to complete analyses within a period as short as two minutes; its ability to analyze samples containing mixtures, without any derivation stages being necessary; its ability to provide highly sensitive and reliable results when an internal standard is used; its suitability for automation; its ability to perform numerous tests within a very short period of time; its ability to perform tests with very small amounts of sample, as little as $20 \mu \mathrm{l}$; and its low ratio of false positive and false negative results.

Owing to factors such as the use of freshly prepared DTT solutions in our study, and the use 
of methanol and formic acid to prepare the mobile phase, the LC-ESI-MS/MS method we employed to measure plasma methionine levels was superior compared to the methods of other studies in terms of better inter-day reproducibility, LOD and LOQ values, shorter retention times, and better mean recovery. Therefore, our study can serve as a reference for the more accurate and exact determination of methionine levels by LC-ESI-MS/MS.

\section{Acknowledgements}

We have no financial interest or conflict of interest in association with this work. This manuscript has not been published previously and is not being considered for publication by another journal. All authors have read and approved the final manuscript.

\section{ВИЗНАЧЕННЯ РІВНЯ МЕТІОНІНУ В ПЛАЗМІ КРОВІ ПАЦІЕНТІВ ІЗ ШИЗОФРЕНІЄЮ МЕТОДОМ LC-ESI-MS/MS}

\section{S. Kulaksizoglu', B. Kulaksizoglu²,}

H. Y. Ellidag', E. Eren ${ }^{l}$, N. Yilmaz ${ }^{l}$, A. Baykal ${ }^{3}$

${ }^{1}$ Central Laboratories of Antalya Education and Research Hospital, Department of Biochemistry, Antalya, Turkey; e-mail: sblclngrgl@yahoo.co.uk;

${ }^{2}$ Antalya Education and Research Hospital, Department of Psychiatry, Antalya, Turkey;

${ }^{3}$ Akdeniz University School of Medicine,

Department of Biochemistry, Antalya, Turkey

Метою нашого дослідження була оцінка рівня метіоніну в плазмі крові пацієнтів із шизофренією з використанням методу тандемної мас-спектрометрії і рідинної хроматографії 3 електроспрей-іонізацією (LC-ESI-MS/MS). Розраховано швидкість відновлення, коефіцієнти варіації (CV), межу виявлення (LOD) і межу кількісного визначення (LOQ). Значення $y$ і $R^{2}$ стандартного графічного рівняння становили $0,011 x+0,0179$ і 0,9989 відповідно. Графік залишався лінійним до 200 мкмоль/л. Протягом дня $\mathrm{CV}$ для зразків $(n=10)$ із рівнем метіоніну 8, 28 i 58 мкмоль/л становили 2,68, 3,10 і 3,79\%, відповідно; а міжденні CV - 2,98, 3,19 і 3,84\%. Значення LOD i LOQ становили 0,04 і 0,1 мкмоль/л, відповідно; середня швидкість відновлення - 101,7 і 99,3\%. Рівень метіоніну в плазмі крові хворих був 21,5 $(19,5-24,6)$ мкмоль/л, у плазмі крові контрольної групи - 17,8 (16,3-20,1) мкмоль/л. Різниця значень між двома групами була статистично значущою
( $p=0,03)$. Проведені дослідження показали, що аналіз із використанням LC-ESI-MS/MS є досить чутливим, економічним, зручним та швидким методом для визначення рівня метіоніну в пацієнтів 3 шизофренією.

К люч ч в і слова: метіонін, метод LCESI-MS/MS, межа виявлення (LOD), межа кількісного визначення (LOQ), пацієнти із шизофренією.

\section{ОПРЕДЕЛЕНИЕ УРОВНЯ МЕТИОНИНА В ПЛАЗМЕ КРОВИ ПАЦИЕНТОВ С ШИЗОФРЕНИЕЙ МЕТОДОМ LC-ESI-MS/MS}

S. Kulaksizoglu', B. Kulaksizoglu², H. Y. Ellidag', E. Eren ${ }^{l}$, N. Yilmaz', A. Baykal

${ }^{1}$ Central Laboratories of Antalya Education and Research Hospital, Department of Biochemistry, Antalya, Turkey; e-mail: sblclngrgl@yahoo.co.uk;

${ }^{2}$ Antalya Education and Research Hospital, Department of Psychiatry, Antalya, Turkey;

${ }^{3}$ Akdeniz University School of Medicine, Department of Biochemistry, Antalya, Turkey

Цель нашего исследования - оценить уровень метионина в плазме крови пациентов с шизофренией с применением метода тандемной масс-спектрометрии и жидкостной хроматографии с электроспрей-ионизацией (LC-ESI-MS/ MS). Рассчитаны скорость восстановления, коэффициенты вариации (CV), предел обнаружения (LOD) и предел количественного определения (LOQ). Значения $y$ и $R^{2}$ стандартного графического уравнения составляли $0,011 x+0,0179$ и 0,9989 соответственно. График оставался линейным до значения 200 мкмоль/л. В течение дня $\mathrm{CV}$ для образцов $(n=10)$ с содержанием метионина 8,28 и 58 мкмоль/л составляли 2,68, 3,10 и $3,79 \%$, соответственно; а междневные $\mathrm{CV}-2,98$, 3,19 и $3,84 \%$. Значения LOD и LOQ составляли 0,04 и 0,1 мкмоль/л, соответственно; средняя скорость восстановления - 101,7 и 99,3\%. Содержание метионина в плазме крови больных было 21,5 (19,5-24,6) мкмоль/л, в плазме крови контрольной группы - 17,8 $(16,3-20,1)$ мкмоль/л. Разница значений между двумя группами была статистически значимой $(p=0,03)$. Проведенные исследования показали, что анализ с использованием LC-ESI-MS/MS является достаточно чувствительным, экономичным, удобным и бы- 
стрым методом определения уровня метионина у пациентов с шизофренией.

К л юче вы е слов а: метионин, метод LC-ESI-MS/MS, предел обнаружения (LOD), предел количественного определения (LOQ), пациенты с шизофренией.

\section{References}

1. Regland B. Schizophrenia and single-carbon metabolism. Prog Neuropsychopharmacol Biol Psychiatry. 2005; 29(7): 1124-1132.

2. Singh SM, Murphy B, O'Reilly RL. Involvement of gene-diet/drug interaction in DNA methylation and its contribution to complex diseases: from cancer to schizophrenia. Clin Genet. 2003; 64(6): 451-460.

3. Calderón-Santiago M, Priego-Capote F, GalacheOsuna JG, Luque de Castro MD. Determination of essential amino acids in human serum by a targeting method based on automated SPE-LCMS/MS: discrimination between artherosclerotic patients. J Pharm Biomed Anal. 2012; 70: 476484.

4. Hellmuth C, Koletzko B, Peissner W. Aqueous normal phase chromatography improves quantification and qualification of homocysteine, cysteine and methionine by liquid chromatography-tandem mass spectrometry. J Chromatogr B. 2011; 879(1): 83-89.

5. Mosharrafa M, Stauffer WM, Reed JH Jr. Recent developments in clinical mass spectrometry. Biomed Sci Instrum. 1971; 8: 71.

6. Cooks RG, Busch KL, Glish GL. Mass spectrometry: analytical capabilities and potentials. Science. 1983; 222(4621): 273-291.

7. Clayton PT. Applications of mass spectrometry in the study of inborn errors of metabolism. J Inherit Metab Dis. 2001; 24(2): 139-150.

8. Lehrer M. In Kaplan LA. Mass spectrometry. St.Louis: Mosby Company. 1996; 167-184.

9. Weaving G, Rocks BF, Iversen SA, Titheradge MA. Simultaneous quantitation of homocysteine, cysteine and methionine in plasma and urine by liquid chromatographytandem mass spectrometry. Ann Clin Biochem. 2006; 43(Pt 6): 474-480.

10. Gardner LA, Desiderio DM, Groover CJ, Hartzes A, Yates CR, Zucker-Levin AR, Bloom L, Levin MC. LC-MS/MS identification of the one-carbon cycle metabolites in human plasma. Electrophoresis. 2013; 34(11):1710-1716.

11. Persichilli S, Gervasoni J, Iavarone F, Zuppi C, Zappacosta B. A simplified method for the determination of total homocysteine in plasma by electrospray tandem mass spectrometry. J Sep Sci. 2010; 33(20): 3119-3124.

12. Li S, Jia J, Liu G, Wang W, Cai Y, Wang Y, $\mathrm{Yu}$ C. Improved and simplified LC-ESI-MS/ MS method for homocysteine determination in human plasma: application to the study of cardiovascular diseases. J Chromatogr B Analyt Technol Biomed Life Sci. 2008; 870(1): 63-67.

13. Pitt JJ. Principles and applications of liquid chromatography-mass spectrometry in clinical biochemistry. Clin Biochem Rev. 2009; 30(1): 19-34.

14. Rafii M, Elango R, House JD, CourtneyMartin G, Darling P, Fisher L, Pencharz PB. Measurement of homocysteine and related metabolites in human plasma and urine by liquid chromatography electrospray tandem mass spectrometry. J Chromatogr B Analyt Technol Biomed Life Sci. 2009; 877(28): 3282-3291.

15. Hempen C, Wanschers H, van der Sluijs Veer G. A fast liquid chromatographic tandem mass spectrometric method for the simultaneous determination of total homocysteine and methylmalonic acid. Anal Bioanal Chem. 2008; 391(1): 263-270.

16. Rafii M, Elango R, Courtney-Martin G, House JD, Fisher L, Pencharz PB. Highthroughput and simultaneous measurement of homocysteine and cysteine in human plasma and urine by liquid chromatography-electrospray tandem mass spectrometry. Anal Biochem. 2007; 371(1): 71-81.

17. Zhang WQ, Hu CQ. Theory of selectivity of RPLC C18 column and its application. Yao Xue Xue Bao. 2010; 45(5): 555-559.

18. Grayson DR, Chen Y, Dong E, Kundakovic M, Guidotti A. From trans-methylation to cytosine methylation: evolution of the methylation hypothesis of schizophrenia. Epigenetics. 2009; 4(3): 144-149.

Received 31.05.2016 